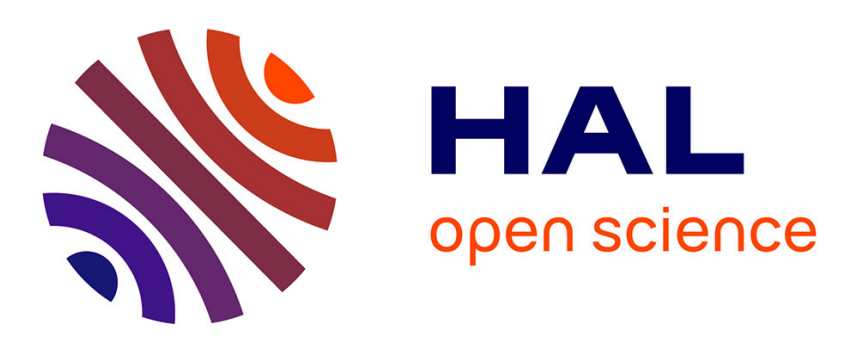

\title{
Corrosion Behavior of 6101 Aluminum Alloy Strands for Automotive Wires
}

\author{
Adrien Laurino, Eric Andrieu, Jean-Paul Harouard, Jacques Lacaze, \\ Marie-Christine Lafont, Grégory Odemer, Christine Blanc
}

\section{- To cite this version:}

Adrien Laurino, Eric Andrieu, Jean-Paul Harouard, Jacques Lacaze, Marie-Christine Lafont, et al.. Corrosion Behavior of 6101 Aluminum Alloy Strands for Automotive Wires. Journal of The Electrochemical Society, 2013, vol. 160 ( $\left.\mathrm{n}^{\circ} 11\right)$, pp. C569-C575. 10.1149/2.080311jes . hal-01165102

\author{
HAL Id: hal-01165102 \\ https://hal.science/hal-01165102
}

Submitted on 18 Jun 2015

HAL is a multi-disciplinary open access archive for the deposit and dissemination of scientific research documents, whether they are published or not. The documents may come from teaching and research institutions in France or abroad, or from public or private research centers.
L'archive ouverte pluridisciplinaire HAL, est destinée au dépôt et à la diffusion de documents scientifiques de niveau recherche, publiés ou non, émanant des établissements d'enseignement et de recherche français ou étrangers, des laboratoires publics ou privés. 


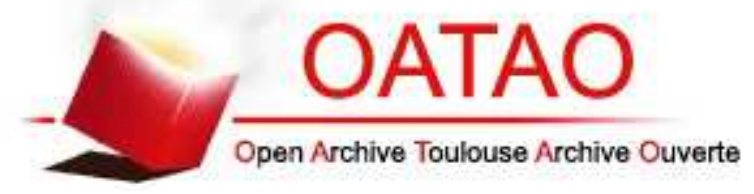

\section{Open Archive TOULOUSE Archive Ouverte (OATAO)}

OATAO is an open access repository that collects the work of Toulouse researchers and makes it freely available over the web where possible.

This is an author-deposited version published in : http://oatao.univ-toulouse.fr/ Eprints ID : 14065

To link to this article : doi: $10.1149 / 2.080311$ jes

URL : http://dx.doi.org/10.1149/2.080311jes

To cite this version : Laurino, Adrien and Andrieu, Eric and Harouard, Jean-Paul and Lacaze, Jacques and Lafont, Marie-Christine and Odemer, Grégory and Blanc, Christine Corrosion Behavior of 6101 Aluminum Alloy Strands for Automotive Wires. (2013) Journal of The Electrochemical Society, vol. 160 ( $\left.\mathrm{n}^{\circ} 11\right)$. pp. C569-C575. ISSN 00134651

Any correspondance concerning this service should be sent to the repository administrator: staff-oatao@ listes-diff.inp-toulouse.fr 


\title{
Corrosion Behavior of 6101 Aluminum Alloy Strands for Automotive Wires
}

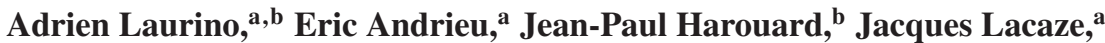 \\ Marie-Christine Lafont, ${ }^{a}$ Gregory Odemer, ${ }^{a}$ and Christine Blanc ${ }^{\mathrm{a}, *, \mathrm{z}}$ \\ ${ }^{a}$ Université de Toulouse, CIRIMAT, UPS/CNRS/INPT, 31030 Toulouse Cedex 04, France \\ ${ }^{b}$ LEONI WIRING SYTEMS FRANCE, 78180 Montigny-le-Bretonneux, France
}

\begin{abstract}
Microstructural states produced by each step of the manufacturing process leading to the production of automotive strand arms in 6101 aluminum alloy (AA6101) for wiring harnesses were investigated in relation to their corrosion behavior in $\mathrm{NaCl}$ solution. The observed corrosion morphology, i.e., pitting corrosion or intergranular corrosion, was strongly dependent on the precipitation state, i.e., mainly the presence of intergranular $\mathrm{Mg}_{2} \mathrm{Si}$ precipitates. A 'grain size - corrosion resistance' relationship was also evidenced with an ennoblement of the corrosion potential for wires heavily cold drawn, which were characterized by a nanometric grain size. Dislocation density as well as the homogeneity of alloying element distribution were also found to be relevant parameters for explaining the electrochemical behavior of each microstructural state. Plastic deformation and recrystallization phenomena occurring during the manufacturing process were found to be associated with redistribution of alloying elements, which impeded the formation of intergranular $\mathrm{Mg}_{2} \mathrm{Si}$ precipitates. Therefore, in the present study, the cold drawing process was found to increase the intergranular corrosion resistance of AA6101.
\end{abstract}

Car manufacturers have developed different solutions to reduce both the cost and weight of vehicle wiring harnesses. One innovative solution is the substitution of copper wires by aluminum alloy wires. Aluminum alloy wires are already used for electrical applications such as high power cables. However, automotive wires require smaller diameter strands. Consequently, aluminum rod is drawn to obtain small diameter strands (about $0.5 \mathrm{~mm}$ ). The thermomechanical process used to manufacture the strand arms consists of several cold-drawing steps with intermediate aging heat treatments. During service, wiring harnesses are submitted to mechanical loading, temperature fluctuations and exposure to various media, such as de-icing salt, which can lead to corrosion damage. Obviously, the corrosion behavior of the harness depends on parameters such as the geometry of the harness (number of strand arms and the space between them) and the intrinsic corrosion behavior of each wire strand. Therefore, improvement of the process and product requires an understanding of the relationship between the manufacturing process and the corrosion behavior of the individual wire strand. Each step in the thermomechanical process modifies the microstructure of the strand and, consequently, its corrosion behavior, so we have evaluated the influence of each step of the manufacturing process on the corrosion behavior of the wire strand.

In this study, the material used to manufacture the strands was a $6101 \mathrm{~T} 4$ aluminum alloy. This is an Al-Mg-Si-Fe alloy with structural hardening resulting from $\beta-\mathrm{Mg}_{2} \mathrm{Si}$ precipitation ${ }^{1-12}$ according to the following precipitation sequence:

$$
\begin{aligned}
& \alpha(\mathrm{SSS}) \rightarrow \text { atomic clusters } \rightarrow \text { GP zones } \rightarrow \beta^{\prime \prime} \rightarrow \beta^{\prime} \\
& \quad \rightarrow \beta-\mathrm{Mg}_{2} \mathrm{Si} \text { (stable) }
\end{aligned}
$$

where SSS means supersaturated solid solution and GP refers to Guinier Preston zones. The presence in the matrix of clusters, of GP zones, $\beta^{\prime \prime}, \beta^{\prime}$ and $\beta$ phases depends on the thermomechanical treatment applied to the material. Coarse intermetallic particles can also be observed in the aluminum matrix. The main intermetallics present in $\mathrm{Al}-\mathrm{Mg}-\mathrm{Si}-\mathrm{Fe}$ alloys are $\mathrm{Fe}$-rich particles such as $\mathrm{Al}_{3} \mathrm{Fe}, \alpha-\mathrm{Al}_{8} \mathrm{Fe}_{2} \mathrm{Si}$, $\beta-\mathrm{Al}_{5} \mathrm{FeSi}$ and $\pi-\mathrm{Al}_{8} \mathrm{FeMgSi}_{6},{ }^{1,13-15}$ and $\mathrm{Mg}_{2} \mathrm{Si}$ precipitates. ${ }^{16}$

The Al-Mg-Si (6xxx series) alloys are generally known as corrosion resistant alloys. However, alloying and thermomechanical treatment can generate susceptibility to pitting corrosion and intergranular corrosion $^{13}$ with corrosion often initiated on coarse intermetallic particles. Blanc et al. ${ }^{17}$ have demonstrated using interferometry and surface observations that $\mathrm{Mg}_{2} \mathrm{Si}$ particles suffer preferential $\mathrm{Mg}$ dissolution after a few seconds of immersion in aggressive media, in agreement with other authors. ${ }^{18,19}$ Preferential initiation of corrosion was then observed at $\mathrm{Mg}_{2} \mathrm{Si}$ sites. ${ }^{17}$ Eckermann et al. have considered that these particles are not preferential sites for pitting corrosion initiation after de-alloying. ${ }^{18}$ The Al-Fe-Si precipitates are cathodic with respect to the aluminum matrix. ${ }^{15,20}$ During immersion in an aggressive media, galvanic cells are created between these intermetallics and the matrix to initiate the dissolution of the surrounding matrix. ${ }^{21}$

Studies focused on Al-Mg-Si alloys with copper have shown that they are susceptible to IGC. Several authors have considered that the susceptibility to IGC of these alloys was due to an extensive precipitation at grain boundaries of $\mathrm{Cu}$-rich precipitates, namely the Q- $\mathrm{Al}_{4} \mathrm{Mg}_{8} \mathrm{Si}_{7} \mathrm{Cu}_{2}$ phase. ${ }^{22,23}$ Hereby, Yamaguchi and Tohma showed that IGC of $\mathrm{Cu}$-containing Al-Mg-Si alloys was caused by a preferential dissolution of very reactive $\mathrm{Mg}_{2} \mathrm{Si}$ precipitates at grain boundaries. $^{24}$ Svenningsen et al. determined that $\mathrm{Cu}$-free Al-Mg-Si alloys would not be susceptible to IGC and that IGC of Al-Mg-Si alloys would be avoided if the $\mathrm{Cu}$-content was below the critical value of $0.1 \mathrm{wt} \% .^{22,25-27}$ These authors considered that $\beta-\mathrm{Mg}_{2} \mathrm{Si}$ precipitates, which are the only intergranular precipitates present in low $\mathrm{Cu}$-content alloys, could not be responsible for IGC susceptibility and that only $\mathrm{Cu}$-rich particles could introduce IGC susceptibility. ${ }^{26}$ However, Bhattamishra and Lal observed IGC for $\mathrm{Cu}$-free 6xxx series alloy and explained their observations on the basis of the activity of $\mathrm{Mg}_{2} \mathrm{Si}$ at grain boundaries. ${ }^{28}$ Moreover, they demonstrated that IGC susceptibility of $\mathrm{Cu}$-free $6 \mathrm{xxx}$ alloys increased with aging treatment which was explained by the formation of $\mathrm{Mg}_{2} \mathrm{Si}$ precipitates at grain boundaries. It is generally agreed that the IGC susceptibility of Al-Mg-Si alloys is reduced by over-aging since this heat-treatment favors the precipitation of coarse precipitates both in the matrix and at grain boundaries. ${ }^{25,26,29}$ This microstructural evolution leads to the depletion in the matrix of some alloying elements. The difference in corrosion potential between the precipitate free zone (PFZ) and the matrix is reduced, thereby decreasing the susceptibility to IGC of the alloy. Several authors have discussed the influence of mechanical deformation, such as extrusion, on IGC susceptibility of 6xxx alloys. They showed that corrosion damage was confined to the recrystallized layer. ${ }^{25,30}$ However, the effect of mechanical deformation on precipitation and consequently on the corrosion behavior has not been considered.

The present paper is probably the first scientific study of the corrosion of aluminum wires for automotive applications. The corrosion behavior of $\mathrm{Cu}$-free AA6101 $(\mathrm{Cu}$ content $<0.02 \mathrm{wt} \%)$ was investigated for each metallurgical state from the first part of the wire drawing process used to manufacture strands. The aim was to explore the 
Table I. Chemical composition (weight\%) of AA6101.

\begin{tabular}{ccccccc} 
& \multicolumn{6}{c}{ Element (wt\%) } \\
\cline { 2 - 7 } AA6101 & $\mathrm{Al}$ & $\mathrm{Mg}$ & $\mathrm{Si}$ & $\mathrm{Fe}$ & $\mathrm{Cu}$ & $\mathrm{Mn}$ \\
\hline & balance & 0.48 & 0.47 & 0.13 & 0.017 & 0.0021
\end{tabular}

influence of the thermo-mechanical history on the corrosion behavior. The microstructure of all samples studied was characterized using optical microscopy (OM), scanning electron microscopy (SEM) and transmission electron microscopy (TEM) and their mechanical properties were evaluated. Their corrosion behavior was studied using conventional electrochemical techniques combined with observations of the sample surface after the corrosion tests.

\section{Experimental}

Materials. - The chemical composition of the AA6101 alloy is given in Table I. It was provided by Rio Tinto Alcan as a $9.5 \mathrm{~mm}$ diameter wire rod made by continuous casting and rolling. This process was followed by water quenching and natural aging to the T4 metallurgical state. The strands were made by a multistep cold drawing process performed by SASA Tréfil'Alu from the T4 wire rod. The first step consisted of cold-drawing at room temperature to make a $1.34 \mathrm{~mm}$ diameter strand. This corresponded to the T3 temper. The second step was a heat-treatment for 10 hours at $185^{\circ} \mathrm{C}$ providing a $\mathrm{T} 8$ temper. Further steps consisted of cold drawing and aging treatments to obtain a $0.51 \mathrm{~mm}$ diameter strand in the T9 state. In this study, only the first steps of the process were studied, which corresponded to the T4, T3 and T8 metallurgical states. Considering the first step of this forming process, the influence of cold working (T3 temper) on the corrosion behavior of AA6101 can be discussed. Considering the second step (T8 temper), the influence of both cold drawing and aging treatment on the corrosion behavior of AA6101 can be investigated. To understand the influence of heat-treatment only, some T4 samples were aged at $185^{\circ} \mathrm{C}$ for 10 hours in the laboratory in an air circulation furnace. These specimens were denoted as T4-A for T4 + Aging. Figure 1 summarizes the first steps of the forming process and the metallurgical states considered in the present work.

Corrosion tests. - For electrochemical measurements, the experimental set-up consisted of a three-electrode electrochemical cell with a large surface area platinum electrode used as a counter electrode and a saturated calomel electrode (SCE) with a Lugin capillary as a reference electrode. All potentials are relative to the SCE reference. The working electrode corresponded to specimens of AA6101 alloy in the previously described metallurgical states. T4 and T4-A samples were machined from the $9.5 \mathrm{~mm}$ diameter rod; they were embedded in an epoxy resin with the transverse section exposed to the electrolyte (surface area corresponding to a $9.5 \mathrm{~mm}$ diameter disk). For T3 and

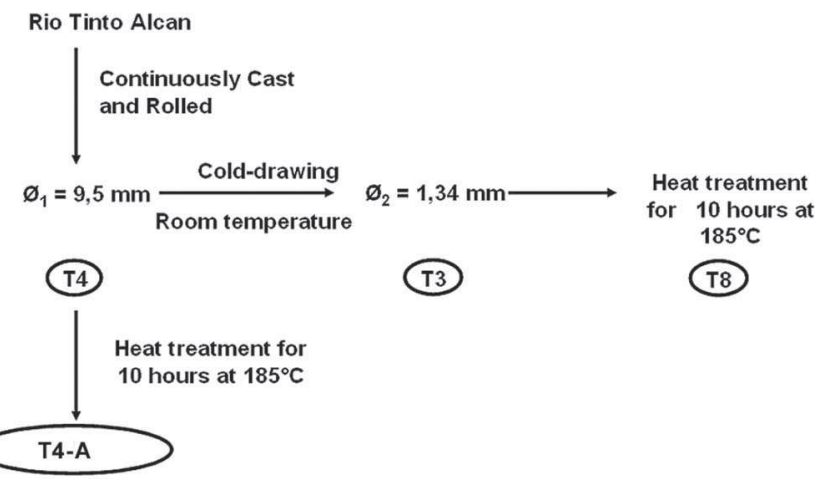

Figure 1. Forming process of the AA6101 strands.
T8 samples, the same preparation was used with a surface area of $1.34 \mathrm{~mm}$ diameter. Before all corrosion tests, the surface of the specimen was mechanically abraded with 4000 grit $\mathrm{SiC}$ papers and then polished to $1 \mu \mathrm{m}$ grade with diamond paste and distilled water as lubricant.

Open circuit potential (OCP) measurements were performed with a test duration of 2 hours. Potentiokinetic polarization experiments were conducted from the potential of $-850 \mathrm{mV} / \mathrm{SCE}$ to the highest potential of $-600 \mathrm{mV} / \mathrm{SCE}$. The potential scan rate was $500 \mathrm{mV} \cdot \mathrm{h}^{-1}$. The electrolyte used for both electrochemical tests was a $0.5 \mathrm{M} \mathrm{NaCl}$ solution at room temperature, open to air and stirred. Solutions were prepared by dissolving Normapur chemical salts in distilled water.

Microstructural observations.- After each electrochemical test, the sample surface was observed and the corrosion damage was characterized using an Olympus PMG3 optical microscope. This microscope was also used to characterize the microstructure of the samples after electrochemical etching. For the T4 metallurgical state, electrochemical etching was repeated twice for $40 \mathrm{~s}$ with $3.5 \mathrm{vol} \% \mathrm{HBF}_{4}$ in distilled water at $20 \mathrm{~V}$ at room temperature. For the T4-A samples, chemical attack was performed for 40 seconds using $5 \mathrm{~mL}$ of $40 \%$ hydrofluoric acid diluted in $995 \mathrm{~mL}$ of distilled water to reveal the grain structure of the samples. Samples were examined using a LEO-435-VP scanning electron microscope (SEM) combined with Energy Dispersive Spectroscopy (EDS) with an accelerating voltage of $15 \mathrm{kV}$. The coarse intermetallics in AA6101 for the different metallurgical states were examined and identified. Transmission electron microscopy (TEM) observations with a JEOL-JEM-2010 microscope provided complementary data on the AA6101 microstructure. The TEM samples were obtained by cutting $280 \mu \mathrm{m}$ thick slices. Then, the slices were ground down to about $100 \mu \mathrm{m}$ thick and a dimple was machined in the central region. Final electron transparency was obtained by ion milling on a precision ion polishing systems (PIPS, Gatan) using $5 \mathrm{kV} \mathrm{Ar}^{+}$ions.

Differential thermal analyzes (DTA) were performed using a Setaram Setsys $16 / 18$. Samples were heated to $610^{\circ} \mathrm{C}$ at $10 \mathrm{~K} \cdot \mathrm{min}^{-1}$.

Mechanical tests. - Vickers hardness measurements with a 100 grams loading were performed on both transverse and longitudinal sections.

\section{Results and Discussion}

Influence of aging treatment on the corrosion behavior of AA6101. - Figure 2a shows that the OCP measured for the T4 samples in a $0.5 \mathrm{M} \mathrm{NaCl}$ solution rapidly stabilized at a value of -790 $\pm 5 \mathrm{mV}$ / SCE, after 200 seconds, whereas OCP for T4-A specimens was shifted to a lower value of $-820 \pm 5 \mathrm{mV} /$ SCE. OM and SEM observations of the electrode surfaces after the OCP tests only showed matrix dissolution around coarse particles for both metallurgical states (Figures 2b, 2c and 2d).

SEM observations and combined EDX analyzes allowed the coarse particles to be identified as Al-Fe-Si particles for T4 and T4-A samples. At this scale, no difference was observed between the two conditions. The coarse particles were spherical with an average diameter of 3-4 $\mu \mathrm{m}$ or plate shaped with average dimensions of 4-5 $\mu \mathrm{m} \times 1$ $\mu \mathrm{m}$. As a result of mechanical rod rolling, they were aligned along the direction of plastic deformation (Figure 3), as previously found. ${ }^{31}$ Figures $4 \mathrm{a}, 4 \mathrm{c}$ and $4 \mathrm{e}$ show the TEM observations of the coarse particles allowing three kinds of particle to be identified in the matrix of AA6101 T4 samples in agreement with the results of Belov et al. ${ }^{1}$ The same result was obtained for T4-A, T3 and T8 conditions. Figure $4 \mathrm{~b}$ is the associated selected area diffraction pattern analysis of a coarse precipitate with a ratio $\mathrm{Fe} / \mathrm{Si}$ of 1 . It corresponded to the $\mathrm{Al}_{9} \mathrm{Fe}_{2} \mathrm{Si}_{2}$ compound characterized by a tetragonal crystal structure $(\mathrm{a}=\mathrm{b}=0.615 \mathrm{~nm}, \mathrm{c}=2.08 \mathrm{~nm}),{ }^{32}$ this compound has also been reported as the $\beta-\mathrm{Al}_{5} \mathrm{FeSi}$ phase by Belov et al. ${ }^{1}$ As shown by Figure $4 \mathrm{~d}$, the second type of coarse precipitates, with a ratio $\mathrm{Fe} / \mathrm{Si}$ equal to 2 , was a $\mathrm{Al}_{17}(\mathrm{Fe}, \mathrm{Mn})_{4} \mathrm{Si}_{2}$ compound (cubic, $\left.\mathrm{a}=1.256 \mathrm{~nm}\right){ }^{32}$ 

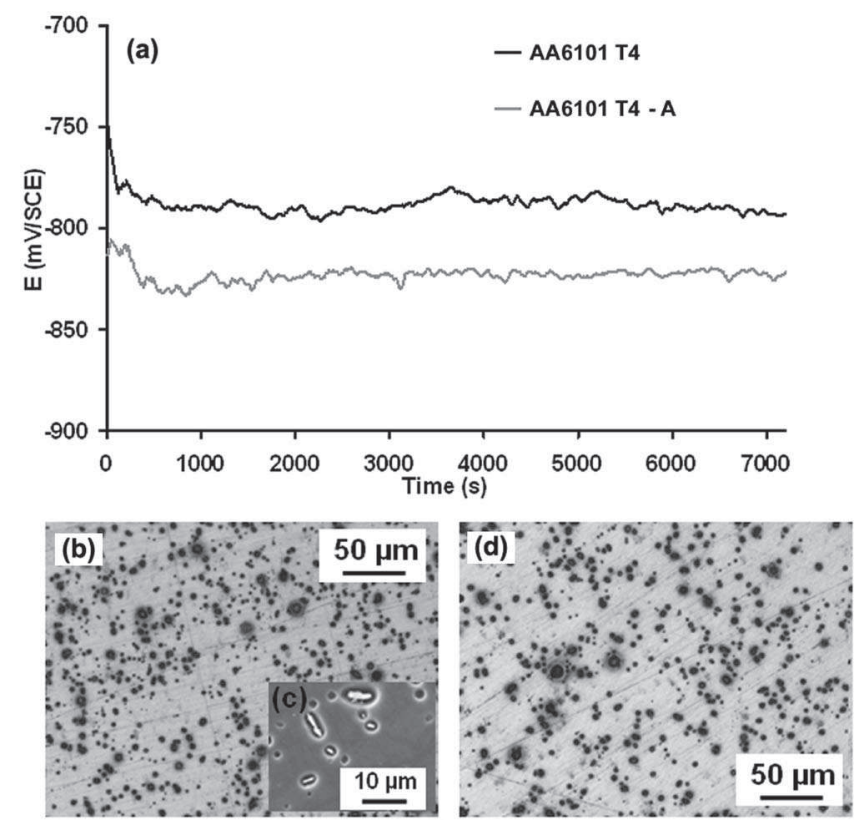

Figure 2. (a) OCP measurements of AA6101 T4 and T4-A in a $0.5 \mathrm{M} \mathrm{NaCl}$ solution (b) OM observations of the T4 samples after OCP (c) SEM observations of the T4 samples after OCP: zoom on intermetallic particles (d) OM observations of T4-A metallurgical state after OCP.

Figure $4 \mathrm{f}$ showed that the third type of coarse precipitates, with a ratio $\mathrm{Fe} / \mathrm{Si}$ of 2, was a $\mathrm{Al}_{7} \mathrm{Fe}_{2} \mathrm{Si}$ compound (hexagonal, $\mathrm{a}=\mathrm{b}=1.2401 \mathrm{~nm}$, $\mathrm{c}=2.634 \mathrm{~nm})^{32}$ corresponding to the $\alpha-\mathrm{Al}_{8} \mathrm{Fe}_{2}$ Si phase. ${ }^{1}$ Figures $2 \mathrm{~b}$, $2 \mathrm{c}$ and $2 \mathrm{~d}$ revealed that all the Al-Fe-Si particles showed the same corrosion behavior and acted as cathodic sites promoting oxygen reduction reaction followed by an associated local $\mathrm{pH}$ increase $\mathrm{s}^{15,20,21}$ and then the dissolution of the surrounding matrix. ${ }^{33-35}$

Figure 5a shows typical current-potential curves for the four metallurgical states. Measurements were repeated at least five times for each metallurgical state; the scattering for the corrosion potential values was evaluated to $\pm 5 \mathrm{mV}$. The results showed that the shape of the curves was the same independent of the metallurgical state. The cathodic part was characterized by a well-defined plateau due to oxygen reduction with a current density of $3( \pm 1) \times 10^{-5} \mathrm{~A} \cdot \mathrm{cm}^{-2}$. Above the corrosion potential, the anodic current density increased rapidly showing that the samples were susceptible to localized corrosion at their corrosion potentials. Comparison of the curves plotted for the $\mathrm{T} 4$ and $\mathrm{T} 4-\mathrm{A}$ samples showed that the $185^{\circ} \mathrm{C}-10$ hours aging led to a decrease of the corrosion potential of AA6101, in good agreement with the OCP measurements. Moreover, the anodic current density measured for the T4-A sample was higher than for the T4 specimen suggesting that the susceptibility to localized corrosion increased af-

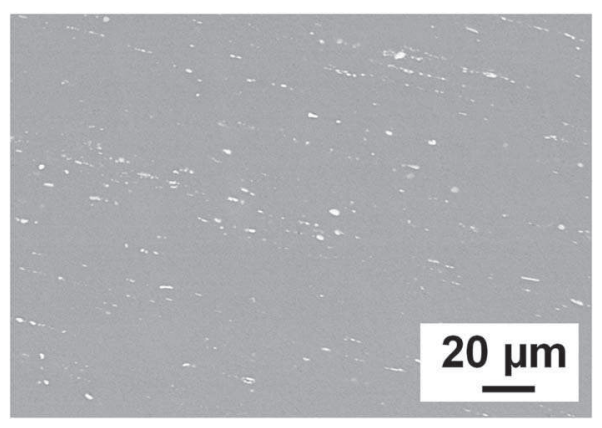

Figure 3. SEM observations of the microstructure of AA6101 T4 in transverse plane.
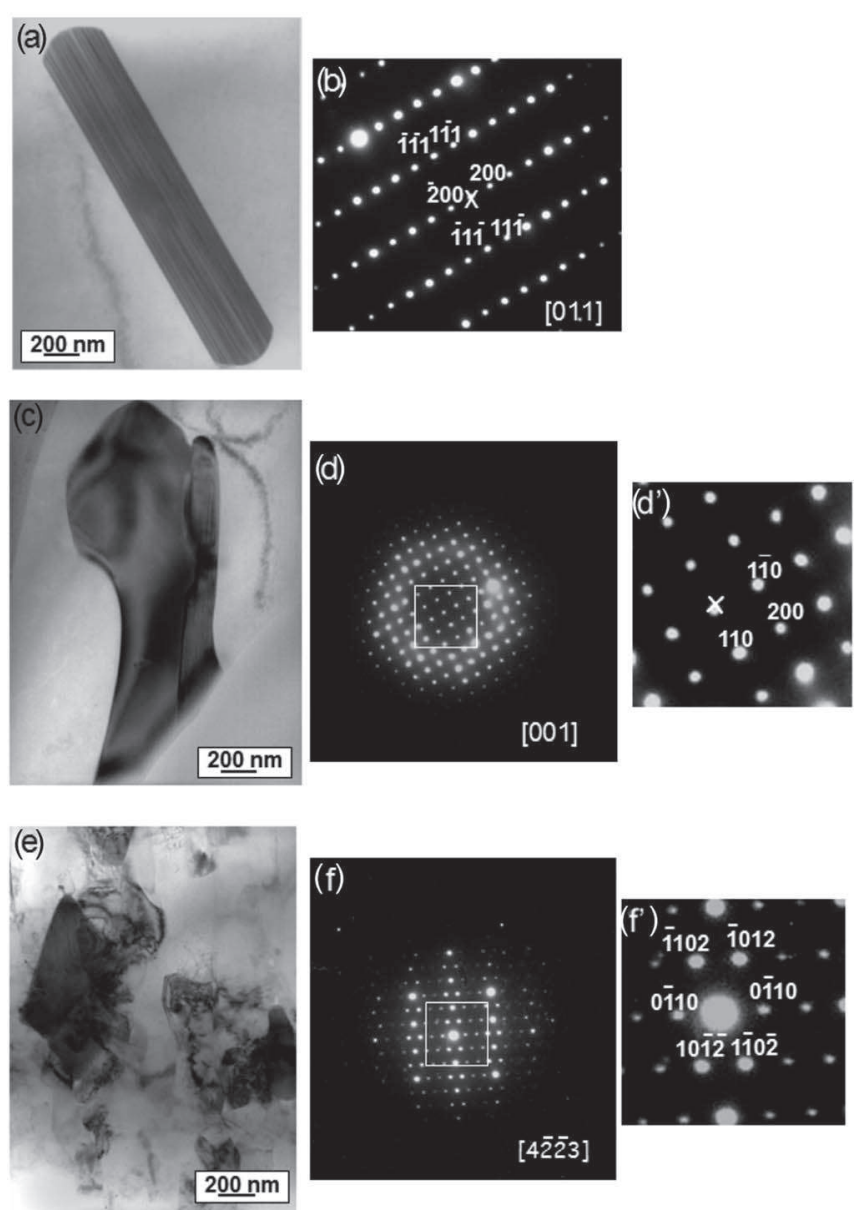

Figure 4. TEM observations of the microstructure of AA6101 T4 (a) $\mathrm{Al}_{9} \mathrm{Fe}_{2} \mathrm{Si}_{2}$ compound (b) selected area diffraction pattern analysis of $\mathrm{Al}_{9} \mathrm{Fe}_{2} \mathrm{Si}_{2}$ compound (c) $\mathrm{Al}_{17}(\mathrm{Fe}, \mathrm{Mn})_{4} \mathrm{Si}_{2}$ compound (d) and (d') selected area diffraction pattern analysis of $\mathrm{Al}_{17}(\mathrm{Fe}, \mathrm{Mn})_{4} \mathrm{Si}_{2}$ compound (e) $\mathrm{Al}_{7} \mathrm{Fe}_{2} \mathrm{Si}$ compound (f) and $\left(\mathrm{f}^{\prime}\right)$ selected area diffraction pattern analysis of $\mathrm{Al}_{7} \mathrm{Fe}_{2} \mathrm{Si}$ compound.

ter the aging treatment with increased corrosion damage. Optical and SEM observations of the electrodes after the potentiokinetic polarization tests showed aluminum matrix dissolution around coarse particles and pitting corrosion for the T4 samples. Around the pit cavities, many fine corrosion filaments were observed (Figure $5 \mathrm{~b}$ ) as already shown for aluminum alloys containing $\mathrm{Al}_{3} \mathrm{Fe}$ particles. ${ }^{36}$ For the T4-A samples, intergranular corrosion, IGC, was also observed (Figure $5 \mathrm{c}$ ).

TEM observations of T4-A samples revealed needles (average dimension $=35 \mathrm{~nm} \times 140 \mathrm{~nm}$ ) or spherical shaped precipitates arranged along the grain boundaries (Figure 6a). EDX and selected area diffraction pattern analyzes identified these intergranular precipitates as $\mathrm{Mg}_{2} \mathrm{Si}$ particles (cubic, $\mathrm{a}=0.635 \mathrm{~nm}$ ). A precipitate free zone (PFZ) was also clearly visible with needle shaped hardening precipitates observed at a distance of about $100-120 \mathrm{~nm}$ from the grain boundaries. The AA6101 T4 specimens did not show hardening or intergranular precipitates (Figure 6b). Due to their size, the hardening precipitates observed for T4-A samples could not be identified by EDX analysis or selected area diffraction pattern analysis. Therefore, DTA was performed to help to identify the precipitation state.

Figure 7 compares the DTA curve obtained upon heating of T4-A samples and that obtained for a T4 specimen. On the vertical axis, arbitrary units were used allowing the DTA signals to be shifted. For the T4 samples, the DTA curve showed two strong exothermic precipitation peaks. The first peak, between $250^{\circ} \mathrm{C}$ and $350^{\circ} \mathrm{C}$, is very broad showing that it can be separated in two peaks marked A and B respectively at $270^{\circ} \mathrm{C}$ and $310^{\circ} \mathrm{C}$. Therefore, the last exothermic 

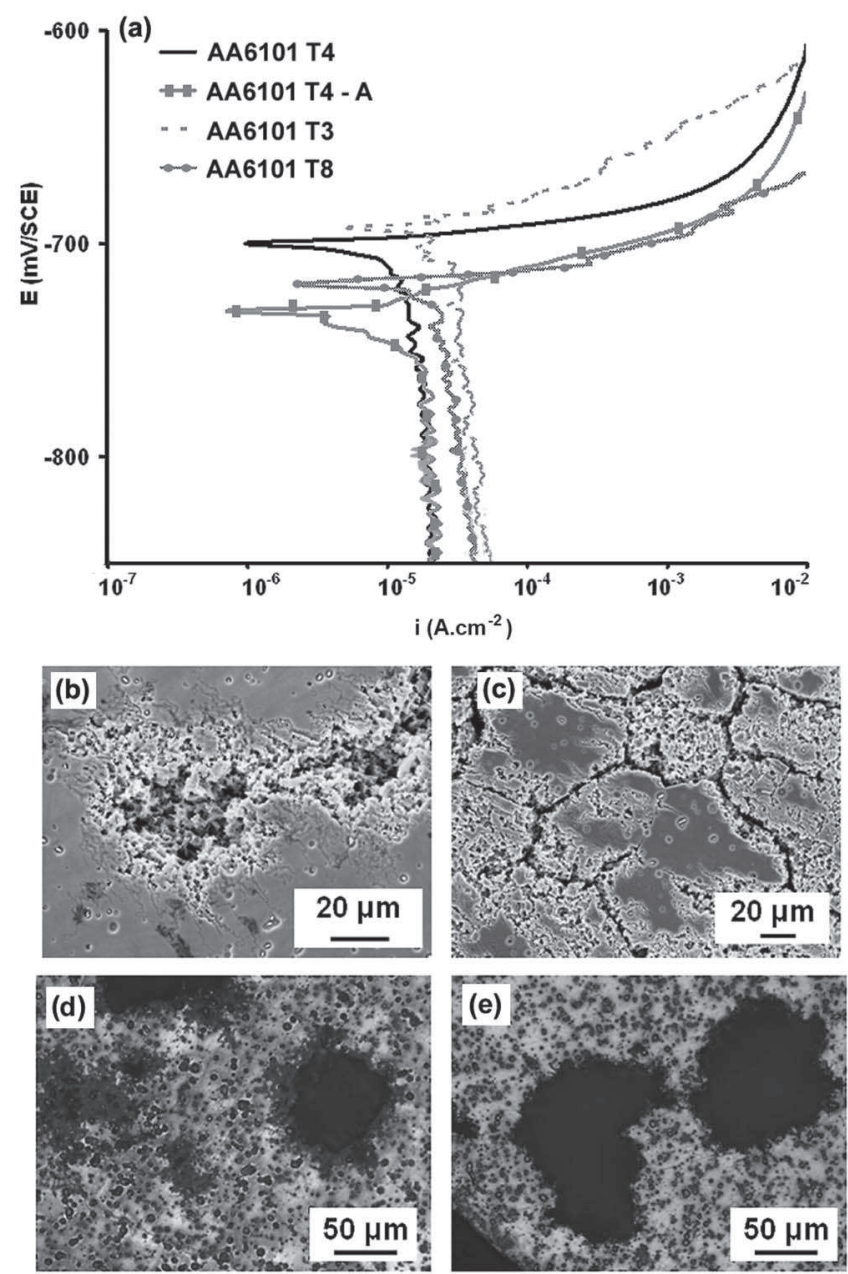

Figure 5. (a) Current-potential curves of the AA6101 T4, T4-A, T3 and T8 samples in a $0.5 \mathrm{M} \mathrm{NaCl}$ solution. Scan rate $=500 \mathrm{mV} . \mathrm{h}^{-1}$. SEM observations after polarization tests of (b) the T4 samples (c) the T4-A samples. OM observations after polarization tests of (d) the T3 samples and (e) the T8 samples.
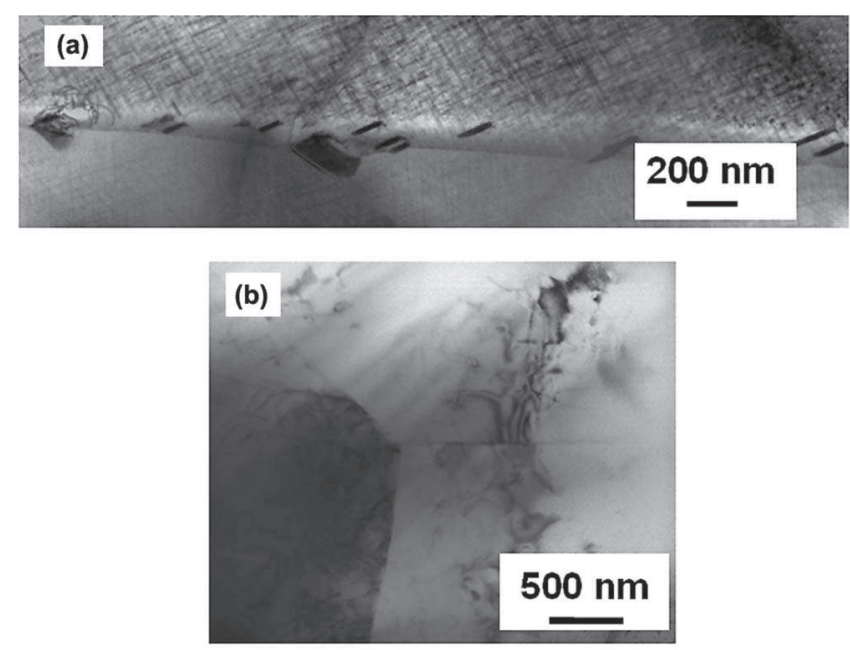

Figure 6. (a) TEM observation of a grain boundary of the AA6101 T4-A microstructural state (b) TEM observation of a grain boundary of the AA6101 T4 sample.

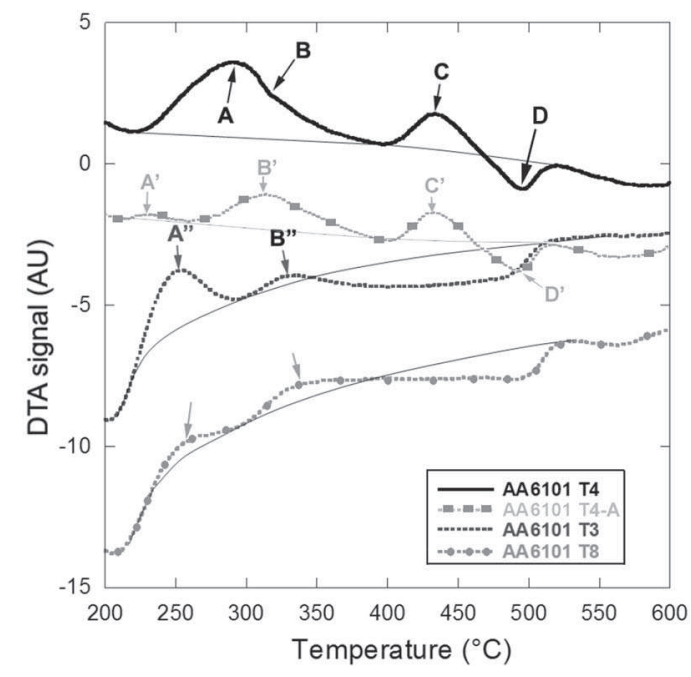

Figure 7. DTA curves for the AA6101 T4, AA6101 T4-A, AA6101 T3 and AA6101 T8 samples. The baseline is plotted for more clarity.

peak, at $430^{\circ} \mathrm{C}$, is marked C. One dissolution arrest marked $\mathrm{D}$ is also observed. Referring to the literature data related to the metallurgy of 6xxx alloys, the three exothermic peaks $\mathrm{A}, \mathrm{B}$ and $\mathrm{C}$ are respectively attributed to the precipitation of $\beta^{\prime \prime}, \beta^{\prime}$ and $\beta$ particles. ${ }^{1-9}$ The presence of these three peaks on the DTA curves confirmed that these precipitates were not present in the T4 sample, in agreement with TEM observations. Concerning the T4-A specimen, DTA curve presented a very small exothermic peak marked $\mathrm{A}^{\prime}$ at $230^{\circ} \mathrm{C}$ and two other peaks, with a much higher intensity, marked $\mathrm{B}^{\prime}$ and $\mathrm{C}^{\prime}$, respectively at $310^{\circ} \mathrm{C}$ and $430^{\circ} \mathrm{C}$. One dissolution arrest marked $\mathrm{D}^{\prime}$ was also observed. $\mathrm{A}^{\prime}$, $\mathrm{B}^{\prime}$ and $\mathrm{C}^{\prime}$ peaks were attributed respectively to the precipitation of $\beta^{\prime \prime}, \beta^{\prime}$ and $\beta$ phases. The very low intensity of $\mathrm{A}^{\prime}$ peak showed that $\beta^{\prime \prime}$ precipitates were already present in the T4-A sample, i.e. that the aging treatment had favored the precipitation of $\beta^{\prime \prime}$ phase from GP zones present in the T4 metallurgical state. Therefore, the first step of the precipitation sequence, from GP zone to $\beta^{\prime \prime}$ phase, was already nearly complete in this case. On the contrary, the presence of strong exothermic peaks $\mathrm{B}^{\prime}$ and $\mathrm{C}^{\prime}$, corresponding to the formation of $\beta^{\prime}$ and $\beta$ phases, suggested that the precipitation process of $\beta-\mathrm{Mg}_{2} \mathrm{Si}$ was not complete after aging treatment for 10 hours at $185^{\circ} \mathrm{C}$, in agreement with literature data. ${ }^{11}$ Therefore, the hardening precipitates observed for the T4-A sample were identified as $\beta^{\prime \prime}$ precipitates for the major part, with maybe some $\beta^{\prime}$ precipitates.

TEM observations were well-correlated with the mechanical properties measured for T4 and T4-A specimens (Table II). The higher hardness values measured for T4-A samples compared to those for T4 specimens were in good agreement with the presence of $\beta^{\prime \prime}$ precipitates in the T4-A matrix while no hardening precipitate was observed for T4 samples. Concerning the corrosion behavior of AA6101 aluminum alloy, the presence of $\mathrm{Mg}_{2} \mathrm{Si}$ intergranular precipitates could explain the susceptibility to IGC of the T4-A samples. This confirms that, for $\mathrm{Cu}$-free 6xxx aluminum alloys, $\mathrm{Mg}_{2} \mathrm{Si}$ intergranular precipitates are anodic sites at grain boundaries promoting the propagation of IGC as reported by several authors ${ }^{24-28}$ and helps to give an answer to the controversy existing in the literature. This supports the data of Buchheit that showed that the corrosion potential of $\mathrm{Mg}_{2} \mathrm{Si}$ precipitates was about $-1600 \mathrm{mV} / \mathrm{SCE}$ in $\mathrm{NaCl}$ solutions compared to the aluminum matrix at about $-700 \mathrm{mV} / \mathrm{SCE}$ in the same electrolyte. ${ }^{16}$ The presence of the PFZ increased the galvanic coupling effect between the grain and the $\mathrm{Mg}_{2} \mathrm{Si}$-decorated grain boundaries in T4-A specimens contributing to the sensitization of AA6101 to intergranular corrosion. The homogeneous distribution of $\beta^{\prime \prime}$ hardening precipitates in the grain (except in the PFZ) and their dissolution due to micro-galvanic coupling with the matrix could affect the corrosion resistance of the grain itself. Therefore, the alloy itself is less resistant 


\begin{tabular}{|c|c|c|c|}
\hline Metallurgical state & $\mathrm{HV}_{0.1}$ & Corrosion behavior & Microstructure \\
\hline $\mathrm{T} 4$ & $61 \pm 3$ & Pitting corrosion & $\begin{array}{l}\text { No hardening precipitates } \\
\text { No intergranular } \mathrm{Mg}_{2} \mathrm{Si} \text { precipitates }\end{array}$ \\
\hline T4-A & $88 \pm 3$ & Intergranular corrosion & $\begin{array}{l}\beta^{\prime \prime} \text { hardening precipitates } \\
\text { Intergranular } \mathrm{Mg}_{2} \mathrm{Si} \text { precipitates }\end{array}$ \\
\hline $\mathrm{T} 3$ & $103 \pm 4$ & Pitting corrosion & $\begin{array}{l}\text { No hardening precipitates } \\
\text { High dislocation density in some grains } \\
\text { No intergranular } \mathrm{Mg}_{2} \mathrm{Si} \text { precipitates }\end{array}$ \\
\hline T8 & $82 \pm 1$ & Pitting corrosion & $\begin{array}{l}\text { No hardening precipitates } \\
\text { No intergranular } \mathrm{Mg}_{2} \mathrm{Si} \text { precipitates }\end{array}$ \\
\hline
\end{tabular}

to corrosion which could explain the shift of the corrosion potential of the T4-A samples toward lower values compared to the T4 samples (Figure 5), as well as that of the OCP (Figure 2).

Influence of cold-drawing on the corrosion behavior of AA6101: role of plastic deformation. - Comparison of the current-potential curves obtained for T4 and T3 metallurgical states (Figure 5) showed that cold working led to a shift of the corrosion potential toward higher values. The corrosion potential of the T8 sample was between those of T4-A and T4 specimens in good agreement with the OCP values. Optical and SEM observations performed after the potentiokinetic polarization tests revealed matrix dissolution around coarse $\mathrm{Al}-\mathrm{Fe}-\mathrm{Si}$ particles and pitting corrosion with filaments for both $\mathrm{T} 3$ and $\mathrm{T} 8$ states (Figure $5 \mathrm{~d}$ and $5 \mathrm{e}$ respectively). No susceptibility to intergranular corrosion was observed for either the $\mathrm{T} 3$ or the T8 samples. The absence of intergranular corrosion for the T8 samples was a key observation. Indeed, due to the aging treatment at $185^{\circ} \mathrm{C}$, the $\mathrm{T} 8$ samples were expected to be susceptible to IGC.

TEM observations showed that neither hardening precipitates nor intergranular $\mathrm{Mg}_{2} \mathrm{Si}$ precipitates were observed for the $\mathrm{T} 3$ samples (Figures $8 \mathrm{a}$ and $8 \mathrm{~b}$ ) as expected. For the T8 samples, TEM observations showed the same result (Figures $9 \mathrm{a}-9 \mathrm{c}$ ) despite the aging treatment at $185^{\circ} \mathrm{C}$ for $10 \mathrm{~h}$. These observations were confirmed by DTA analyzes (Figure 7). For T3 samples, a medium intensity exothermic peak, marked $\mathrm{A}^{\prime \prime}$, was observed at $250^{\circ} \mathrm{C}$ : that could be attributed to $\beta^{\prime \prime}$ precipitation from GP zones, as proposed previously for T4 samples. This result confirmed that $\beta^{\prime \prime}$ precipitates were not present in the T3 samples. Secondly, contrary to T4 samples, only a very smooth exothermic peak, marked $\mathrm{B}^{\prime \prime}$ at $325^{\circ} \mathrm{C}$, corresponding to the formation of $\beta^{\prime}$ phase and no peak for $\beta$ phase were observed showing that the formation of $\beta^{\prime}$ and $\beta$ phases occurred to a very limited extent upon heating during DTA analyzes for the T3 samples. Similar results were obtained for the T8 metallurgical state for which two small exothermic peaks corresponding to $\beta^{\prime \prime}$ and $\beta^{\prime}$ precipitation from GP zones were observed while no peak was observed corresponding to the precipitation of $\beta$ phase.

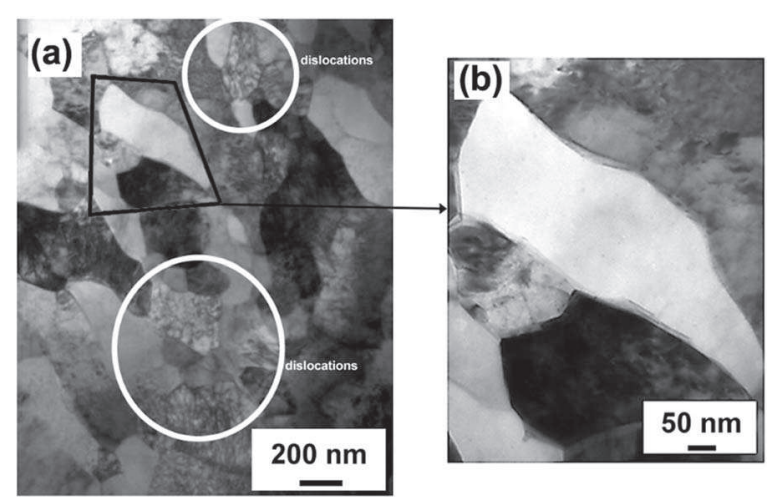

Figure 8. (a) TEM observations of the AA6101 T3 samples (b) zoom on previous micrograph.
The absence of hardening precipitates and intergranular precipitates for the cold drawn samples, in particular for the T8 samples, was another key observation of this study. Indeed, this is not conventionally found in these alloys as for example after high shear deformation processes like rolling, grinding machining or even wire drawing. Because of this, the DTA experiments were repeated at various scanning rates, and the results were checked. DTA experiments showed high reproducibility. TEM observations were also repeated and the absence of hardening precipitation and intergranular precipitates was confirmed. Moreover, additional data were obtained. Indeed, measurements at the grain size of etched T4 and T4-A samples by using an optical microscope showed an average grain diameter of about $80-100 \mu \mathrm{m}$ in transverse section (Figure 10). In longitudinal section, the grain size was about $200 \mu \mathrm{m}$ near the surface of the wire and about $130 \mu \mathrm{m}$ in the core of the material. For T3 and T8 samples, the grain size was too small to be measured on the basis of optical or SEM observations of etched samples. The TEM observations for the T3 samples revealed grains, with an average size of about $100-500 \mathrm{~nm}$ in transverse section that were elongated in the direction of cold drawing (Figures $8 \mathrm{a}$ and $8 \mathrm{~b}$ ).
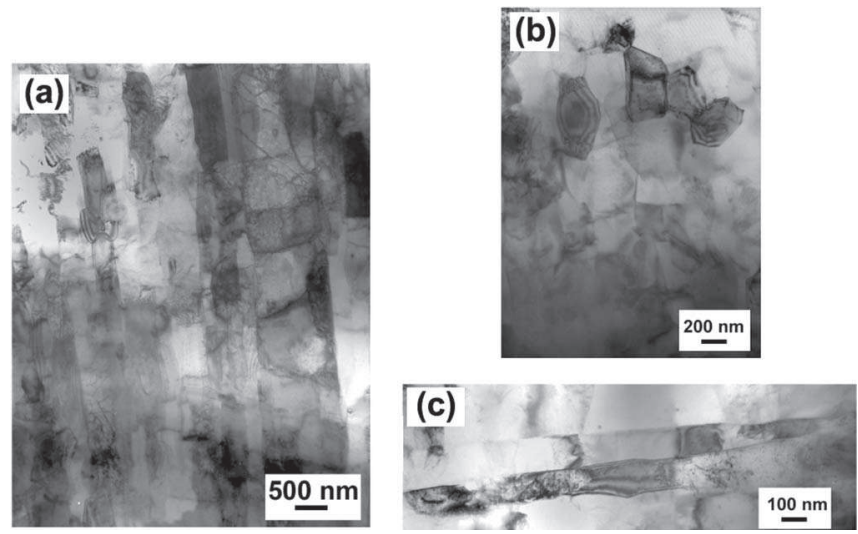

Figure 9. (a), (b) and (c) TEM observations of the AA6101 T8 samples.

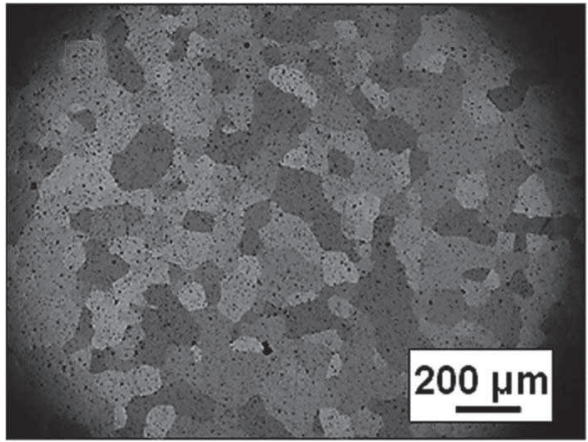

Figure 10. OM observation in polarized light of an AA6101 T4 sample. 
The TEM observations also showed a heterogeneous distribution of the dislocations in the material (Figure 8a). The samples were tilted in different directions to confirm the observations. This specific morphology of the grains combined with the high density of dislocations for some grains showed that the cold-drawing process led to the formation of a nanostructure and, consequently, to a strength increase (Table II). The nanostructure could be explained by a dynamic recrystallization phenomenon which occurred during the first cold-drawing steps and was followed by an additional plastic deformation of the grains since the reduction in rod diameter from $9.5 \mathrm{~mm}$ to $1.34 \mathrm{~mm}$ was obtained by passing the strands through a series of drawing dies. For the T8 specimens, TEM observations showed a strong heterogeneity in the grain size in the transverse plane: some grains with an average size of about $3 \mu \mathrm{m}$ and others with an average size of about $100-500 \mathrm{~nm}$ were observed (Figures 9a-9c). This suggested that the aging treatment of 10 hours at $185^{\circ} \mathrm{C}$ performed on the T3 nanostructure led to a partial static recrystallization, in good agreement with the softening of the material from the microhardness measurements (Table II). TEM observations and the interpretation of the DTA records led us to assume that the cold drawing process used for the samples, leading to a severe plastic deformation, at a very high deformation rate (the strain rate measured during the cold drawing process was about $100 \mathrm{~km} \cdot \mathrm{h}^{-1}$ ), impeded or delayed the precipitation sequence in the grains as well as the precipitation of $\mathrm{Mg}_{2} \mathrm{Si}$ intergranular precipitates during the following aging treatment even at temperatures as high as $185^{\circ} \mathrm{C}$ and for a duration of 10 hours (aging for T8 samples). Therefore, a decrease of the IGC susceptibility of the alloy was observed. This could be related to the recrystallization phenomena observed; dislocation displacement associated with this phenomenon could lead to a redistribution of the alloying elements so that local chemical supersursaturation disappeared which delayed and/or impeded the formation of $\beta^{\prime \prime}, \beta^{\prime}$ and $\beta$ phases. Further study has been undertaken.

It is worth noticing that the absence of intergranular precipitation for the T8 samples is an unexpected result but it is in good agreement with the corrosion behavior observed (Figure 5), confirming the hypothesis that intergranular $\mathrm{Mg}_{2} \mathrm{Si}$ precipitation promotes IGC susceptibility for $\mathrm{Cu}$-free $6 \mathrm{xxx}$ aluminum alloys. ${ }^{28}$ Other consequences from the cold drawing process (grain size and dislocation density) could also contribute to explain the properties of the strand arms. A grain size effect could explain the shift of the corrosion potential for $\mathrm{T} 3$ samples with respect to T4 ones (Figure 5) as previously mentioned by many authors who found a tendency for the intergranular corrosion rate to decrease and an ennoblement of the corrosion potential as the grain size decreases. ${ }^{37-39}$ The high dislocation density for the T3 samples could also affect their corrosion behavior as suggested by Luo et al. who showed that there was a relationship between the dislocation density in a grain and the ability of the grain boundary to be corroded. ${ }^{40}$ Moreover, it should be relevant to consider a difference in the grain boundary character distribution (GBCD) between the T4 and the T3 metallurgical states. This parameter could also partly explain the results as suggested by Kim et al. who showed that the GBCD has a great effect on intergranular corrosion susceptibility of aluminum in $\mathrm{HCl}^{41}$ The influence of the grain size could also partly explain the results for the T8 samples. With a finer grain size than the T4-A samples, the T8 samples were expected to have a nobler corrosion potential, in good agreement with the experimental results (Figure 5). The growth of some grains for T8 samples during aging, compared to T3 samples, was assumed to lead to a shift of the corrosion potential of this metallurgical state toward lower potential compared to that for T3 sample, in good agreement with the results (Figure 5). However, as noticed by Ralston et al. ${ }^{37}$ the 'grain size - corrosion resistance' relationship is complex and this complexity could be increased due to the heterogeneity of the grain size in a sample. For T8 samples, a bimodal microstructure was observed which could contribute to explain the corrosion behavior of this metallurgical state. ${ }^{42}$ Moreover, the severe plastic deformation led also to a fragmentation of the $\mathrm{Al}-\mathrm{Fe}-\mathrm{Si}$ coarse particles, in agreement with the observations of Adamczyk-Cieslak et al. for a 6060 aluminum alloy. ${ }^{43}$ This could be associated with the multiplication of pit sites, promoting pitting corrosion and decreasing the susceptibility to IGC of the T8 samples, in agreement with Brunner et al. ${ }^{39}$

\section{Conclusions}

The corrosion behavior of AA6101 in different metallurgical states corresponding to the different steps of the manufacturing process of wire harnesses was studied in chloride solution. In the manufacturing process, the initial material was in the T4 state; it was submitted to different cold drawing steps followed by an aging treatment at $185^{\circ} \mathrm{C}$ for $10 \mathrm{~h}$ to obtain the strand arms constitutive of the harnesses. The results presented herein showed that the intergranular precipitation state dominated the corrosion morphology observed for AA6101 with intergranular corrosion susceptibility observed for the metallurgical states characterized by the presence of intergranular $\mathrm{Mg}_{2} \mathrm{Si}$ precipitates. However, the global corrosion behavior of the alloy resulted from the combination of the effects of several metallurgical factors including grain size, alloying element distribution, precipitation and dislocation density. These parameters were strongly related to the manufacturing route and interrelated. For example, a 'grain size corrosion resistance' relationship was evidenced with cold drawing process generating a nanostructure characterized by a higher potential compared to that of the $\mathrm{T} 4$ samples. The formation of the nanostructure was correlated to the absence of intergranular $\mathrm{Mg}_{2}$ Si precipitates due to a redistribution of the alloying elements induced by dislocation displacement associated with a recrystallization phenomenon. Therefore, in the case of this study, the cold working due to the cold-drawing protected the alloy against intergranular corrosion by impeding the formation of $\mathrm{Mg}_{2} \mathrm{Si}$ phases at the grain boundaries even if the material was heat-treated at $185^{\circ} \mathrm{C}$ for 10 hours after cold drawing. The results gave a new insight into the corrosion behavior of aluminum wire. This is a key point for the properties of the product and for its in service-durability.

\section{Acknowledgments}

The material studied was provided by Rio Tinto Alcan and cold drawn by SASA Trefil'Alu. The authors thank Didier Albert (Rio Tinto Alcan) and Jean-Jacques Zyla (SASA Trefil'Alu).

\section{References}

1. N. A. Belov, D. G. Eskin, and A. A. Aksenov, Multicomponent Phase Diagrams: Applications for Commercial Aluminum Alloys, first edition, Elsevier Ltd, Oxford, (2005).

2. A. Lutts, Acta Metall., 9(6), 577 (1961).

3. A. Guinier and H. Lambot, Rev. Metall., 47, 709 (1950).

4. G. Thomas, J. I. Met., 90, 57 (1961-1962).

5. D. W. Pashley, J. W. Rhodes, and A. Sendorek, J. I. Met., 94, 41 (1966).

6. C. D. Marioara, S. J. Andersen, J. Jansen, and H. W. Zandbergen, Acta Mater, 49(2), $321(2001)$.

7. H. S. Hasting, A. G. Froseth, S. J. Andersen, R. Vissers, J. C. Walmsey, C. D. Mariora, F. Danoix, W. Lefebvre, and R. Holmestad, J Appl. Phys, 106, 123527 (2009).

8. K. Matsuda, T. Naoi, K. Fujii, Y. Uetani, T. Sato, A. Kamio, and S. Ikeno, Mater. Sci. Eng. A, A262, 232 (1999).

9. K. Matsuda, Y. Sakaguchi, Y. Miyata, Y. Uetani, T. Sato, A. Kamio, and S. Ikeno, $J$. Mater. Sci., 35, 179 (2000)

10. A. K. Gupta, D. J. Lloyd, and S. A. Court, Mater. Sci. Eng. A, A301, 140 (2001).

11. A. K. Gupta, D. J. Lloyd, and S. A. Court, Mater. Sci. Eng. A, 316, 11 (2001).

12. G. A. Edwards, K. Stiller, G. L. Dunlop, and M. J. Couper, Acta Mater, 46(11), 3893 (1998).

13. L. F. Mondolfo, Aluminum Alloys: Structure and Properties, Butterworths \& Co. Ltd, London, (1976).

14. Y. L. Liu, S. B. Kang, and H. W. Kim, Mater. Lett., 41, 267 (1999).

15. S. Karabay, M. Yilmaz, and M. Zeren, J. Mater. Process. Tech., 160, 138 (2005).

16. R. G. Buchheit, J. Electrochem. Soc., 142, 3994 (1995).

17. C. Blanc, Y. Roques, and G. Mankowski, Corros. Sci., 40, 1019 (1998).

18. F. Eckermann, T. Suter, P. J. Uggowitzerb, A. Afseth, and P. Schmutz, Electrochim. Acta, 54, 844 (2008).

19. K. Mizuno, A. Nylund, and I. Olefjord, Corros. Sci., 43(2), 381 (2001).

20. Z. Szklarska-Smialowska, Corros. Sci., 41, 1743 (1999).

21. H. Ezuber, A. El-Houd, and F. El-Shawesh, Mater. Des., 29, 801 (2008) 
22. G. Svenningsen, J. E. Lein, A. Bjorgum, Y. Yu, and K. Nisancioglu, Corros. Sci., 48(1), 226 (2006)

23. V. Guillaumin and G. Mankowski, Corros. Sci., 42(1), 105 (2000).

24. K. Yamaguchi and K. Tohma, J. Jpn. Inst. Light Met., 47(5), 285 (1997).

25. G. Svenningsen, M. H. Larsen, J. H. Nordlien, and K. Nisancioglu, Corros. Sci, 48(1), 258 (2006)

26. G. Svenningsen, M. H. Larsen, J. H. Nordlien, and K. Nisancioglu, Corros. Sci., 48 , 3969 (2006).

27. G. Svenningsen, M. H. Larsen, J. C. Walmsley, J. H. Nordlien, and K. Nisancioglu, Corros. Sci., 48(6), 1528 (2006).

28. A. K. Bhattamishra and K. Lal, Mater. Des., 18(1), 25 (1997).

29. V. Guillaumin and G. Mankowski, Corrosion, 56(1), 12 (2000)

30. T. Minoda and H. Yoshida, Metall. Mater. Trans. A, 33A(9), 2891 (2002)

31. G. Mrowka-Nowotnik and J. Sieniawski, J. Mater. Process. Tech., 162-163, 367 (2005).
32. P. Villars, Pearson's Hanbook: Crystallographic Data for Intermettalics Phases, second edition, Materials Park, OH : ASM International, (1997).

33. J. O. Park, C. H. Paik, and R. C. Alkire, J. Electrochem. Soc., 143, L174 (1996).

34. J. O. Park, C. H. Paik, Y. H. Huang, and R. C. Alkire, J. Electrochem. Soc., 146, 517 (1999)

35. W. C. Moshier, G. D. Davis, and J. S. Ahearn, Corros. Sci., 27, 785 (1987).

36. R. Ambat, A. J. Davenport, G. M. Scamans, and A. Afseth, Corros. Sci., 48, 3455 (2006).

37. K. D. Ralston, D. Fabijanic, and N. Birbilis, Electrochim. Acta, 56, 1729 (2011).

38. K. D. Ralston, N. Birbilis, and C. H. J. Davies, Scripta Mater, 63, 1201 (2010).

39. J. G. Brunner, N. Birbilis, K. D. Ralston, and S. Virtanen, Corros. Sci., 57, 209 (2012).

40. C. Luo, X. Zhou, G. E. Thompson, and A. E. Hughes, Corros. Sci., 61, 35 (2012).

41. S. H. Kim, U. Erb, and K. T. Aust, Scripta Mater, 44, 835 (2001).

42. S. Gollapudi, Corros. Sci., 62, 90 (2012).

43. B. Adamczyk-Cieslak, J. Mizera, and K. J. Kurzydlowski, Mater. Charact., 62, 25 (2011). 